\title{
Association between the consumption of antioxidant nutrients with lipid alterations and cardiometabolic risk in adolescents
}

\section{Associação entre o consumo de nutrientes \\ antioxidantes com alterações lipídicas e risco cardiometabólico em adolescentes}

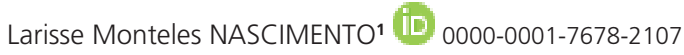 \\ Keila Rejane Oliveira GOMES² (D) 0000-0001-9261-8665 \\ Marcio Denis Medeiros MASCARENHAS ${ }^{1}$ (D) 0000-0001-5064-2763 \\ Cassio Eduardo Soares MIRANDA ${ }^{1}$ (D) 0000-0002-8990-1205 \\ Telma Maria Evangelista de ARAÚJO3 (D) 0000-0001-5628-9577 \\ Karoline de Macedo Gonçalves FROTA4 (iD) 0000-0002-9202-5672
}

\section{Objective}

This study aimed at validating the associations between the consumption of antioxidant nutrients as well as lipid alterations and cardiometabolic risks in adolescents.

\footnotetext{
${ }^{1}$ Universidade Federal do Piauí, Centro de Ciências da Saúde, Programa de Pós-Graduação em Saúde e Comunidade. Teresina, PI, Brasil.

2 Universidade Federal do Piauí, Colégio Técnico de Teresina, Departamento de Enfermagem. Teresina, PI, Brasil.

${ }^{3}$ Universidade Federal do Piauí, Departamento de Enfermagem. Teresina, PI, Brasil.

${ }^{4}$ Universidade Federal do Piauí, Centro de Ciências da Saúde, Programa de Pós-Graduação em Alimentos e Nutrição, Campus Ministro Petrônio Portela, Av. Universitária s/n., 64049-550, Ininga, Teresina, PI, Brasil. Correspondência paral Correspondence to: KMG FROTA. E-mail: <karolfrota@ufpi.edu.br>.

Article based on the master thesis of LM NASCIMENTO, entitled "Prevalência de fatores de risco cardiovascular e sua associação com nutrientes em adolescentes". Universidade Federal do Piauí; 2017.
}

Como citar este artigo/How to cite this article

Nascimento LM, Gomes KRO, Mascarenhas MDM, Miranda CES, Araújo TME, Frota KMG. Association between the consumption of antioxidant nutrients with lipid alterations and cardiometabolic risk in adolescents. Rev Nutr. 2018;31(2):183-97. http://dx.doi.org/10.1590/1678-98652018000200005 


\section{Methods}

This cross-sectional study included 327 adolescents aged 14-19 years. Sociodemographic and dietary information, anthropometric and blood pressure measurements, and biochemical data were obtained. Cardiometabolic risk was calculated by aggregating the risk factors, which were expressed as the sum of Z-scores. Poisson regression was performed to estimate the prevalence ratios.

\section{Results}

In boys, low intake of zinc was associated with elevated total cholesterol and triglyceride levels, whereas it was associated with low high-density lipoprotein cholesterol levels and high low-density lipoprotein cholesterol and total cholesterol levels in girls, thus indicating a cardiometabolic risk. Furthermore, low intake of copper was associated with high triglyceride levels and cardiometabolic risk in girls. The high prevalence ratios of high low-density lipoprotein cholesterol and total cholesterol levels and cardiometabolic risk were higher in those with low intake of vitamin A. Among girls, associations were also observed between lower intake of vitamin A and high triglyceride levels. Low intake of vitamin $C$ among boys was associated with elevated high low-density lipoprotein cholesterol and triglyceride levels. Among girls, the intake of this vitamin was associated with lower low high-density lipoprotein cholesterol levels. In girls, low intake of vitamin E was associated with low low high-density lipoprotein cholesterol levels and high total cholesterol levels.

\section{Conclusion}

The associations between antioxidant micronutrients as well as lipid alterations and cardiometabolic risk emphasize the importance of encouraging the consumption of foods that are rich in these nutrients to modulate lipid alterations and cardiometabolic risk.

Keywords: Adolescents. Antioxidants. Food consumption. Lipid metabolism disorders. Cardiovascular disease.

\section{RE S U M O}

\section{Objetivo}

Esta pesquisa teve como objetivo verificar as associações entre o consumo de nutrientes antioxidantes e as alterações lipídicas e o risco cardiometabólico em adolescentes.

\section{Métodos}

Trata-se de estudo transversal com 327 adolescentes de 14 a 19 anos de idade. Investigaram-se dados sociodemográficos, antropométricos, pressóricos, bioquímicos e de consumo alimentar. O risco cardiometabólico foi calculado por meio da agregação dos fatores de risco, expressa pela soma dos escores $Z$. Realizou-se a regressão de Poisson para estimar as razões de prevalência.

\section{Resultados}

O baixo consumo de zinco associou-se a elevados níveis de CT e triglicérides para os meninos, e a níveis baixos de HDL-c e elevados de LDL-c e CT para as meninas, demonstrando risco. Além disso, a baixa ingestão de cobre associou-se a altos níveis de triglicérides e risco cardiometabólico para as meninas. A razão de prevalência nos níveis elevados de $L D L-C, C T$ e risco cardiometabólico foi maior entre os adolescentes que apresentavam baixa ingestão de vitamina $A$. Foram observadas também associações, no sexo feminino, da menor ingestão de vitamina A com altos níveis de triglicérides. A baixa ingestão de vitamina $C$ nos meninos mostrou associações com LDL-c e triglicérides elevado, enquanto nas meninas essa vitamina associou-se com menores níveis de $H D L-c$. O baixo consumo de vitamina E, para as meninas, apresentou associações com níveis baixos de HDL-c e elevados de CT.

\section{Conclusão}

As associações entre os micronutrientes antioxidantes e as alterações lipídicas e risco cardiometabólico ressaltam a importância de estimular o consumo de alimentos que sejam fonte desses nutrientes, com o objetivo de modular as alterações lipídicas e o risco cardiometabólico.

Palavras-chave: Adolescentes. Nutrientes antioxidantes. Consumo de alimentos. Transtorno do metabolismo dos lipídeos. Doenças cardiovasculares. 


\section{INTRODUCTION}

Lipid alterations are risk factors for the development of Cardiovascular Diseases (CVD) and generally appear during infancy and adolescence; they may contribute to the development of CVD in adulthood [1]. Low-Density Lipoprotein Cholesterol (LDL-C) is responsible for transporting cholesterol to the arteries. In contrast, High-Density Lipoprotein Cholesterol (HDL-c) performs reverse cholesterol transport and has an antiatherogenic effect [2].

In cases of elevated LDL-c levels, it may become more atherogenic due to the increased oxidation of these particles. In general, oxidative stress and vascular inflammation are associated with endothelial dysfunction and vascular damage. The correlation is highly significant that pro-inflammatory alterations in the endothelial cells are considered the stimulants of cellular adhesion molecules and the release of cytokines, which are markers of endothelial dysfunction. Oxidative stress is a process that can be modulated by the consumption of antioxidant nutrients, which is similar to atherosclerosis [3-6].

Previous studies have suggested that the intake of antioxidant nutrients, such as Zinc (Zn), Copper (Cu), Selenium (Se), and vitamins A, C, and $E$, protect against oxidative damage and its associated complications [7-10]. A meta-analysis showed that an increase of one portion per day in the consumption of fruits and vegetables is associated with a lower risk for mortality from CVD. The risk for mortality declined by $4 \%$ for each additional portion per day of fruits and vegetables, by $5 \%$ for each additional portion per day of fruits, and by $4 \%$ for each additional portion per day of vegetables [11].

Alimentary habits adopted during adolescence are important public health concerns, considering that there is a direct association between poor dietary habits and the occurrence of obesity and other chronic diseases during adulthood [12]. The Study of Cardiovascular Risk Factors in Brazilian Adolescents showed that adolescents maintain the consumption of traditional foods, such as rice and beans, and that the intake of sugary beverages and highly processed foods is high. Along with this alimentary profile, the excessive consumption of saturated fatty acids and free sugars and a high prevalence of inadequate intake of micronutrients were also observed [13].

Considering that studies that evaluate the consumption of antioxidant nutrients, such as $\mathrm{Zn}, \mathrm{Cu}$, and vitamins $\mathrm{A}, \mathrm{C}$, and $\mathrm{E}$, in teenagers are limited and most studies have examined the association between isolated micronutrients and chronic alterations, it is important to identify the amount of micronutrients that is consumed and the association between these micronutrients and biochemical indices and the risk of developing diseases in young populations. This may then stimulate the establishment of public health policies that encourage the consumption of fruits and vegetables that are rich in these nutrients, thus improving the adolescents health over time. Therefore, this study aimed at verifying the association between the consumption of antioxidant nutrients as well as lipid alterations and cardiometabolic risk in adolescents.

\section{METHODS}

\section{Description of the study and the population}

This is a cross-sectional study on adolescents aged between 14 and 19 years who were enrolled in public and private schools in the urban area of Teresina, Piauí, in 2016. The study is part of a project of the Universidade Federal do Piaui entitled "Health in the School: A Situational Diagnosis of Secondary Schools."

\section{Sampling plan}

The schools were selected via probability sampling [14], with strata based on the type of administration and geographical area and size. 
One public and one private school were selected for each size: small (up to 115 students), medium (116-215 students), and large (more than 215 students). In this study, the researcher chose the geographic area corresponding to each Regional Educational Administration (GRE), with a total of 12 public and 12 private schools.

In selecting the adolescent participants, stratified proportional random sampling was carried out [14]. The Epi Info 6.04d program (Centers for Disease Control and Prevention, Atlanta, United States of America) was utilized to calculate the minimum sample size, starting from 40,136 secondary school students in private and state public schools, which is in accordance with the 2014 School Census [15]. Moreover, 95.0\% Confidence Intervals $(95.0 \% \mathrm{Cl}$ ) were obtained: the prevalence of obesity, $17.1 \%$ [16]; precision, 5.0\%; design effect, 1.4\%; and significance level, 5.0\% [17]. This baseline study section required at least 304 students. Assuming that there will be a decrease in the number of participants during data collection, an additional $10.0 \%$ of the sample was randomly selected in each school, yielding a final sample of 334 adolescents.

The sample of schools that were selected was distributed in proportion to the number of adolescents per type of school administration and size, and the sample designated for each school that was selected was randomly assigned based on grade level, sex, and age.

The study was conducted in accordance with Resolution 466/2012 of the National Health Counsel [18] and approved by the research ethics committee of the Universidade Federal do Piauí ( $\left.n^{\circ} 1.495 .975\right)$. Informed consent was obtained from the parents of the participants or the responsible parties. For the study participants aged below 18 years, an informed consent was also obtained.

\section{Anthropometry}

Weight and height were measured based on the guidelines of Cameron [19] and Jellife \&
Jellife [20]. A portable electronic scale (SECA ${ }^{\circledR}$, model 803, Hamburg, Germany), with 100-g precision, was used to weigh the participants, and height was measured using a stadiometer (SECA ${ }^{\circledR}$, Messband model 206, Hamburg, Germany), with $0.1-\mathrm{cm}$ precision. Body Mass Index (BMI) was expressed in Z-scores and classified in accordance with guidelines of the World Health Organization. The following cutoff values were used: thinness percentile $\geq 0.1$ and $<3$; eutrophia percentile $\geq 3$ and $<85$; and obesity, percentile $>85$ and $\leq 97$ [21].

The technique of Callaway et al. [22] was utilized to measure Waist Circumference (WC) using an inelastic measuring tape (SECA ${ }^{\circledR}$, model 201, Hamburg, Germany), with 0.1-cm precision. The measurements were compared using the curve of Fredriks et al. [23], utilizing the cut-off value for obesity (percentile $\geq 90$ ). The Waist-To-Height Ratio (WHtR) was obtained by measuring the participants' WC and height. A cut-off value of 0.50 was utilized, which is the proposed limit to be used in the diagnosis of excessive abdominal fat in adolescents [24].

\section{Assessment of alimentary consumption}

The 24-hour alimentary record (R24H) was utilized to obtain data regarding alimentary consumption. In filling out the record, the multiple pass [25] method was utilized. The second $\mathrm{R} 24 \mathrm{H}$ was utilized in $40 \%$ of the population, with a 2-month interval to correct for interpersonal variability [26]. The Nutwin software (version 1.6.0.7) of the Department of Information Science in Health of the Universidade Federal de São Paulo was utilized to calculate the quantities of $\mathrm{Zn}, \mathrm{Cu}$, and Se as well as vitamins $\mathrm{A}, \mathrm{C}$, and $\mathrm{E}$.

Nutrients were adjusted for interpersonal variability using the Multiple Source Method (MSM) software version 1.0.1 (2011; the Department of Epidemiology of the German Institute for Human Nutrition, PotsdamRehbrucke, Nuthetal, Brandenburg, Germany), which estimates usual consumption [27]. 


\section{Arterial pressure}

Arterial Pressure (AP) was obtained in accordance with the guidelines of the 7th Brazilian Guidelines on Arterial Pressure [28] utilizing a calibrated aneroid sphygmomanometer (Model DS-44, Welch Allyn Tycos ${ }^{\circledR}$ Durashock, New York, United States of America), with appropriate arm cuff sizes for the adolescents' arm circumference. The means of the two measurements for Systolic Arterial Pressure (SAP) and Diastolic Arterial Pressure (DAP), obtained initially and after 5 minutes of rest, were calculated [29]. If the difference between the measurements of AP was greater than $5 \mathrm{mmHg}$, two additional measurements were obtained, and their means were utilized for analysis [30]. The adolescents were classified as normotensive if the SAP and DAP were below the $90^{\text {th }}$ percentile for their height that is relative to sex and age [28].

\section{Biochemical profile}

Blood sample $(5 \mathrm{~mL})$ was collected by nurses on school premises after fasting for $12 \mathrm{~h}$. To determine serum lipid levels, the samples were cooled in a tube without anticoagulants. The levels of HDL-C, Total Cholesterol (TC), Triglycerides (TG), and blood glucose were obtained using the colorimetric enzymatic method (ModeloBioSystems 310, Curitiba, Paraná, Brazil) along with the Labtest ${ }^{\circledR}$ kits. The Friedwald [31] formula was utilized to calculate LDL-C levels. The serum lipid measurements were classified in accordance with the Fifth Brazilian Guidelines on Dyslipidemia and Prevention of Atherosclerosis, and the reference values are as follows: TC level $<170 \mathrm{mg} / \mathrm{dL}$; LDL-C level $<110 \mathrm{mg} / \mathrm{dL} ; \mathrm{HDL}-\mathrm{C}$ level $>45 \mathrm{mg} / \mathrm{dL}$; and TG level <90mg/dL [2]. Glucose levels were classified in accordance with the criteria defined by the American Diabetes Association, and the reference value is $<100 \mathrm{mg} / \mathrm{dL}$ [32].

\section{Cardiometabolic risk score}

Cardiometabolic risk was classified in accordance with the cardiovascular risk factors, expressed as continuous variables by the sum of the Z-scores for each factor that was evaluated [33]. Mean Arterial Pressure (MAP) was calculated in accordance with the MAP formula $=([$ systolic AP diastolic AP)/3] + diastolic AP. The metabolic risk scores were obtained for the following variables: MAP, WC, and LDL-C, TC, TG, and glucose levels, using the formula Z-score $=[$ (reading-mean) $/ \mathrm{SD}]$. For HDL-c levels, the scores were obtained using the inverse of the formula, considering that it is inversely related to cardiovascular risk. An individual with a Z-score $\geq 1$ SD was at higher risk [34].

\section{Statistical analysis}

Data were analyzed using SPSS software (Statistical Package for Social Sciences, for Windows $^{\circledR}$ version 22.0, SPSS Inc., Chicago, Illinois, United States). The chi-squared test was utilized to verify the association between the prevalence of high glucose levels and lipid alterations and cardiometabolic risk in terms of sex. The intake of antioxidant nutrients was expressed in tercile.

Bivariate analysis was conducted using an unadjusted Poisson regression. The poststratification weights based on the type of school administration and the number of adolescents in the GRE of the respective school were considered. With the estimation of variance and the aim of calculating the Prevalence Ratio (PR) between the outcome variables (lipid alterations and cardiometabolic risk score) and the explanatory variables (antioxidant nutrients), the Poisson regression was used, with robust variance adjustment for both adjusted and nonadjusted analysis. In the analysis, sex was utilized as a possible interacting variable. Variables with a $p$-value $<0.20$ in the unadjusted analysis were used in the multivariate analysis, and to control possible confounding factors, sex, age, mother's schooling, and type of school were adjusted. A $p$-value $<0.05$ was considered statistically significant. 


\section{RE S U L T S}

Of the 348 participants, 21 were excluded, of which 11 refused and others had hemolysis of blood samples. Thus, the final sample consisted of 327 adolescents. Table 1 shows the data on the significant prevalence of glycemic alterations as well as the increased consumption of $\mathrm{Zn}, \mathrm{Cu}$, and vitamin $\mathrm{A}$ in boys. However, the TC level, cardiometabolic risk, and intake of vitamin $\mathrm{E}$ were significantly higher in girls than in boys.

All the independent variables used in the bivariate analysis in both sexes (Table 2 ) were included in the multivariate analysis $(p<0.20)$.

Table 3 presents the results of the analysis on the variables after adjustment. Results showed that the low intake of $\mathrm{Zn}$ was associated with high TC and TG levels in boys $(p<0.05)$. Moreover, an association was observed between low intake of vitamin A and high LDL-C and TC levels and cardiometabolic risk. Intake of vitamin $C$ was associated with high LDL-C and TG levels. Furthermore, in girls, a significant association was observed between low intake of $\mathrm{Zn}$ and high LDL-C and TC levels and low $\mathrm{HDL}-\mathrm{c}$ levels. $\mathrm{Cu}$ also was associated with high levels of TG and cardiometabolic risk. The low consumption of vitamin A was also considered a risk factor since it was associated with high TG levels. Furthermore, low intake of vitamin $C$ was significantly associated with low HDL-c levels. Vitamin E was also associated with low HDL-c levels and increased cardiometabolic risk.

\section{DISCUSSION}

Changes in glucose and TC levels in girls were highly prevalent in this study. These results are in accordance with the findings of a study involving Brazilian adolescents, particularly girls [35]. However, the prevalence of high blood glucose levels was lower in the present study [36].
Regarding the association between the intake of antioxidant nutrients as well as lipid alterations and cardiometabolic risk, the high prevalence of these biochemical alterations was associated with the low consumption of these micronutrients (except for Se; data not presented in this study). These results show the effect of these antioxidants on the overall health of the population. It is not just a question on the lipid profile but also on the cardiometabolic risk, which was calculated considering anthropometric and biochemical risk factors.

Although the effects of $\mathrm{Zn}$ on the metabolism of lipoproteins are still controversial, studies have confirmed the effects of this mineral on the lipid profile of humans $[37,38]$. The associations between the low intake of $\mathrm{Zn}$ and low HDL-c levels and high TC and TG levels in boys as well as the LDL-C, TC, and HDL-c level in girls were validated in this study, showing that this nutrients cause lipid profile alterations. Kadhim et al. [39] have reported that the oral supplementation of Zn lowers LDL-C, TC, and TG levels in patients with diabetes.

Data show that $\mathrm{Zn}$ can act as an endogenous factor that protects an individual against atherosclerosis, inhibiting the oxidation of $L D L-c$ by reactive oxygen species in the presence of transition metals. In addition, the appropriate alimentary consumption of $\mathrm{Zn}$ protects an individual against inflammatory diseases, such as atherosclerosis, by inhibiting the activation of transcription factors that are responsive to oxidative stress as well as the expression of inflammatory cytokines. This mineral can also partly block genes that codify inflammatory cytokines, such as interleukin- 6 and interleukin-8, in the endothelial cells [39]. This result emphasized the importance of adequately consuming $\mathrm{Zn}$ as well as other micronutrients, such as $\mathrm{Cu}$, which may be beneficial for the health.

$\mathrm{Cu}$ is a component of ceruloplasmin and Cu-Zn superoxide dismutase, which plays an important role in biochemical functions related to the enzymatic components of the antioxidant 
Table 1. Prevalence of glucose and lipid levels, cardiometabolic risk, and the consumption of antioxidant nutrients in terms of sex. Teresina (PI), 2017.

\begin{tabular}{|c|c|c|c|c|c|c|}
\hline \multirow{2}{*}{ Variables } & \multicolumn{2}{|c|}{ Boys } & \multicolumn{2}{|c|}{ Girls } & \multirow{2}{*}{$95 \% \mathrm{Cl}$} & \multirow{2}{*}{$p$-value } \\
\hline & $n$ & $\%$ & $\mathrm{n}$ & $\%$ & & \\
\hline Glucose level (mg/dL) & & & & & $1.79-5.75$ & 0.00 \\
\hline$<100$ & 93 & 28.4 & 174 & 53.3 & & \\
\hline$\geq 100$ & 38 & 11.6 & 22 & 6.7 & & \\
\hline \multicolumn{7}{|l|}{ Lipid profile (mg/dL) } \\
\hline LDL-C & & & & & $0.65-1.60$ & 0.92 \\
\hline$<110$ & 66 & 20.2 & 98 & 30.0 & & \\
\hline$\geq 110$ & 64 & 19.8 & 93 & 28.4 & & \\
\hline $\mathrm{HDL}-\mathrm{C}$ & & & & & $0.65-1.59$ & 0.94 \\
\hline$\leq 45$ & 59 & 18.0 & 88 & 27.0 & & \\
\hline$>45$ & 73 & 22.3 & 107 & 32.7 & & \\
\hline TC & & & & & $0.40-0.98$ & 0.04 \\
\hline$<170$ & 66 & 20.2 & 77 & 23.5 & & \\
\hline$\geq 170$ & 65 & 19.9 & 119 & 36.4 & & \\
\hline TG & & & & & $0.67-2.13$ & 0.55 \\
\hline$\geq 90$ & 25 & 7.6 & 32 & 9.8 & & \\
\hline$<90$ & 106 & 32.4 & 162 & 49.5 & & \\
\hline Cardiometabolic risk & & & & & $1.81-6.87$ & 0.00 \\
\hline Low & 30 & 9.2 & 15 & 4.6 & & \\
\hline High & 102 & 31.2 & 180 & 55.0 & & \\
\hline \multicolumn{7}{|c|}{ Food consumption or Dietary intake } \\
\hline Zinc & & & & & & 0.00 \\
\hline 1st tercile & 38 & 11.6 & 86 & 26.3 & & \\
\hline 2nd tercile & 41 & 12.5 & 72 & 22.1 & & \\
\hline 3rd tercile & 53 & 16.2 & 37 & 11.3 & & \\
\hline Copper & & & & & & 0.00 \\
\hline 1st tercile & 12 & 3.7 & 115 & 35.2 & & \\
\hline 2nd tercile & 38 & 11.6 & 75 & 22.9 & & \\
\hline 3rd tercile & 82 & 25.1 & & & & \\
\hline Vitamin A & & & & & & 0.02 \\
\hline 1st tercile & 36 & 11.0 & 71 & 21.7 & & \\
\hline 2nd tercile & 47 & 14.4 & 72 & 22.0 & & \\
\hline 3rd tercile & 41 & 12.5 & 36 & 11.0 & & \\
\hline Vitamin C & & & & & & 0.00 \\
\hline 1st tercile & 71 & 21.7 & 39 & 12.0 & & \\
\hline 2nd tercile & 26 & 8.0 & 85 & 25.9 & & \\
\hline 3rd tercile & 35 & 10.7 & 71 & 21.7 & & \\
\hline Vitamin $E$ & & & & & & 0.60 \\
\hline 1st tercile & 43 & 13.1 & 66 & 20.2 & & \\
\hline 2nd tercile & 63 & 19.3 & 101 & 30.8 & & \\
\hline 3rd tercile & 25 & 7.6 & 29 & 9.0 & & \\
\hline
\end{tabular}

Note: N=327; LDL-C: Low-Density Lipoprotein; HDL-C: High-Density Lipoprotein; TC: Total Cholesterol; TG: Triglycerides. 95\% Cl: 95\% Confidence Interval. Chi-squared test. 


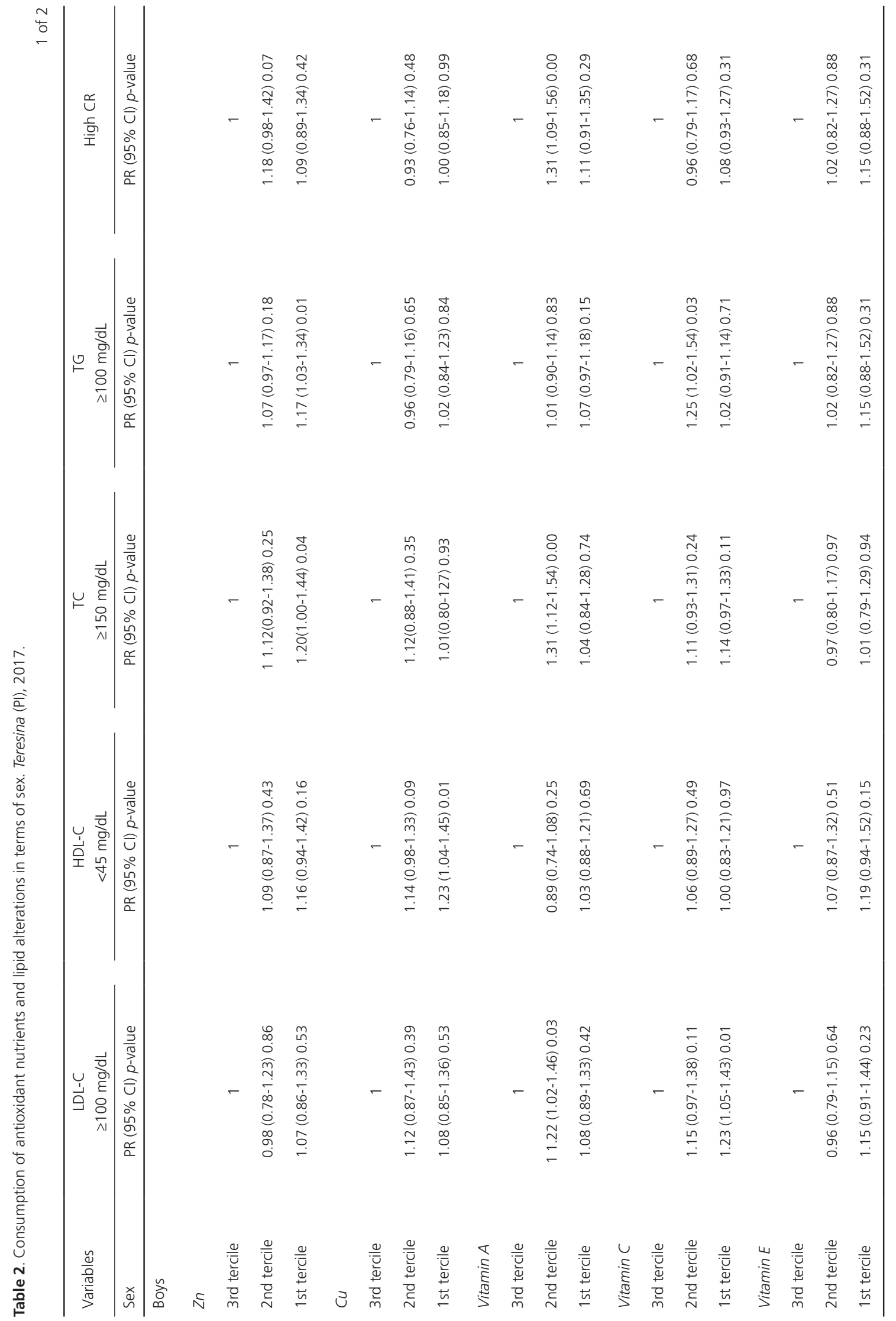




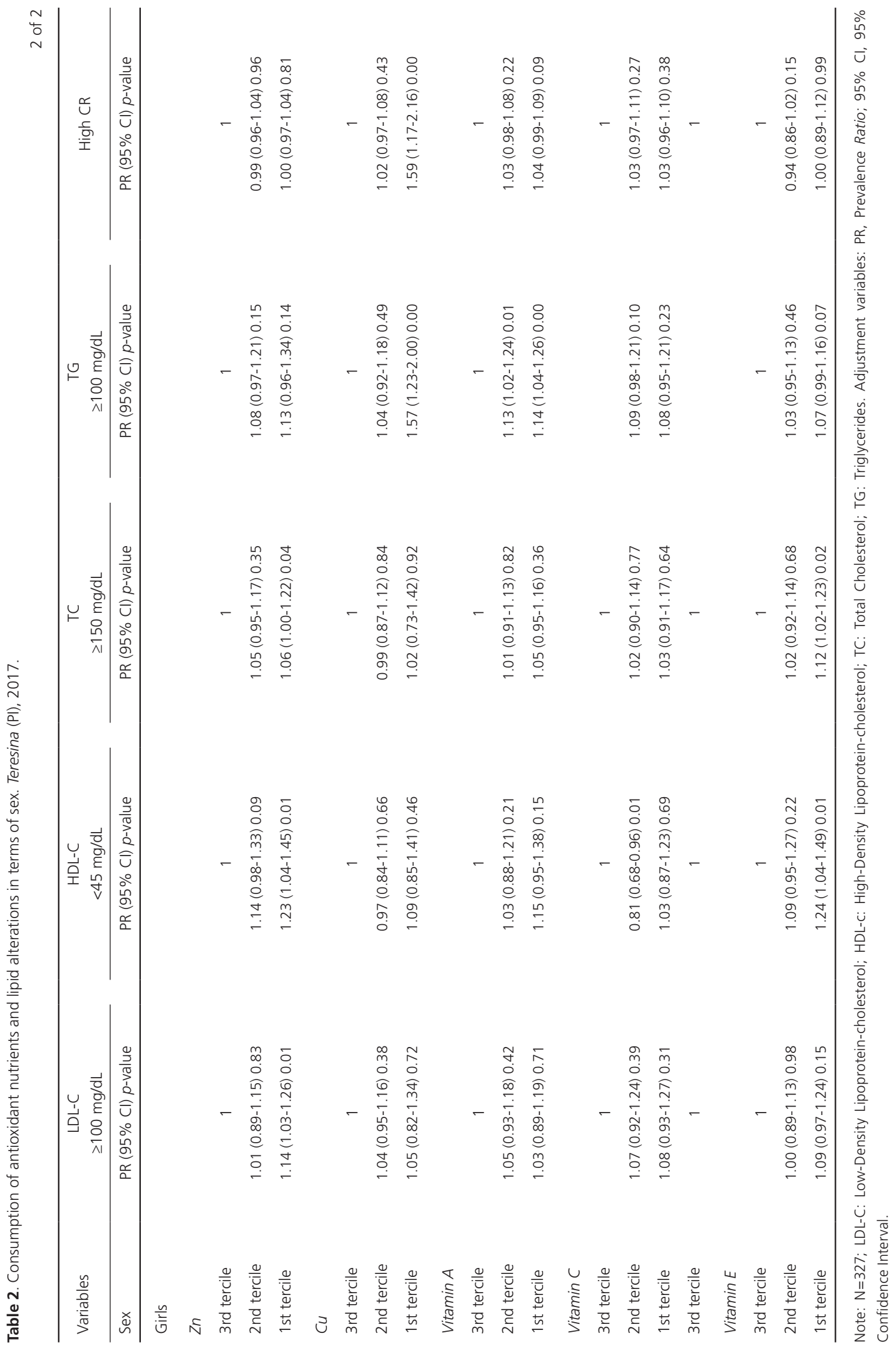




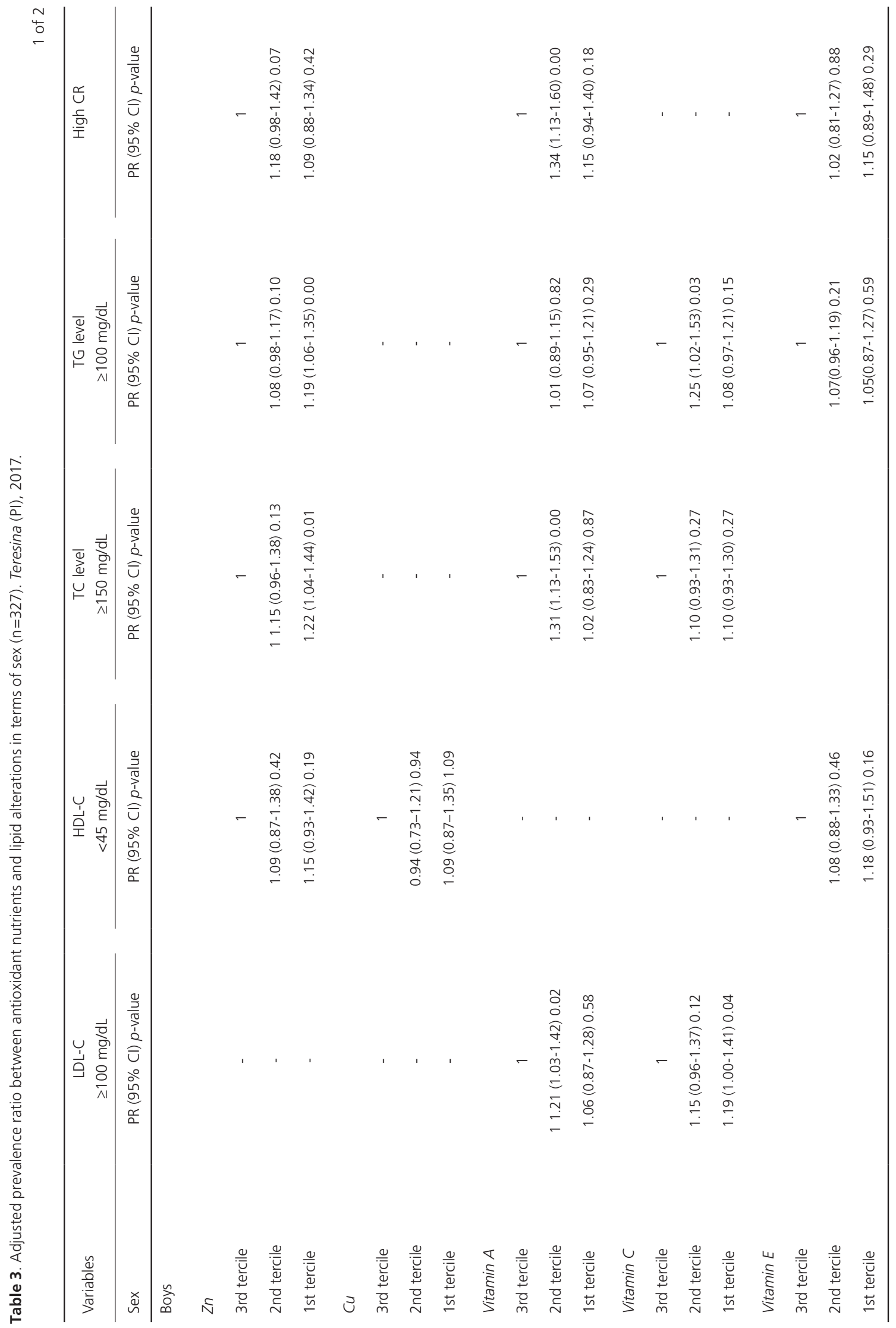




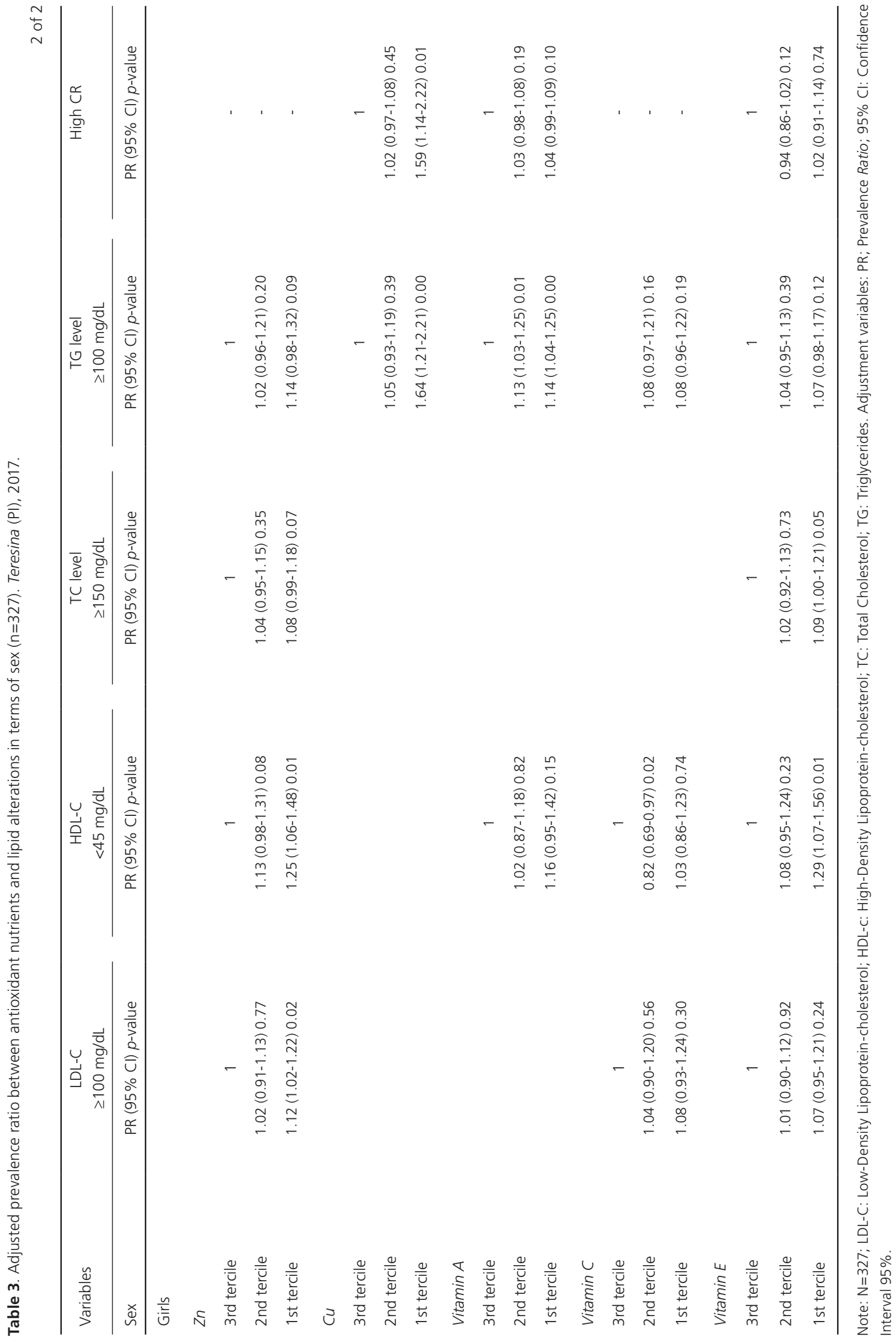


defense system. Therefore, increased susceptibility to oxidative damage can be one of the biological consequences that contribute to pathological Cu deficiency, along with hypercholesterolemia, and predisposition to CVD [40]. The results of this study indicate the associations between low intake of $\mathrm{Cu}$ as well as high TC level and cardiometabolic risk, which are the risk factors in women. These data remain controversial because the study by Suarez-Ortegón et al. [7] did not show an association between the consumption of $\mathrm{Cu}$ as well as lipid levels and metabolic syndrome in adolescents.

Regarding the consumption of vitamins in boys, associations were observed between low intake of vitamin A and elevated LDL-c and TC levels and cardiometabolic risk. In girls, low intake of vitamin A was associated with high TG levels. Low intake of vitamin $\mathrm{E}$ was associated with lower HDL-c levels and high TC levels. Another study has shown that the concentrations of vitamins $A$ and $E$ were positively correlated with the levels of $T G, T C$, and $L D L-C$ in children [8]. Retinol binding-protein was also associated with high lipid levels, particularly TG levels, in children in Switzerland [41]. These results may be explained by the roles of vitamins $A$ and $E$ in lipid metabolism. Vitamin $A$ is associated with lipid metabolism via the retinaldehyde dehydrogenase enzyme 1, whereas vitamin $E$ is involved in this process mainly because it protects the lipids from oxidation and prevents oxidative damage. Thus, high lipid levels will require a high intake of vitamins $A$ and $E$ [42].

A meta-analysis of randomized trials has shown that supplementation with vitamin C significantly reduced LDL-c levels in healthy participants. However, it did not positively affect HDL levels [43]. These results are in accordance with those of the present study in which a decreased intake of vitamin C was associated with elevated LDL-C and TG levels among boys. However, low intake of vitamin C was also associated with low HDL-c levels in girls.

The benefits of vitamin $C$ can be explained by the fact that this vitamin is a cofactor of enzyme 7 - $\alpha$-hydroxylase, which is the rate limiting enzyme in the synthesis of bile acid [44]. In the liver, the conversion of cholesterol into bile acids can increase the expression of LDL-C receptors in the hepatocytes [45]. This will lead to greater capture of LDL-C in the circulation and lower its concentrations in the blood. Since vitamin C facilitates the conversion of cholesterol into bile acids, this can help reduce cholesterol concentration in the blood [46]. Another possible mechanism involves the role of vitamin $C$ as an antioxidant. By inhibiting the oxidation of LDL-C, vitamin $C$ facilitates its binding and absorption with the help of the LDL-c receptors in the hepatocytes [44].

Micronutrient deficiencies are mainly caused by an unhealthy diet [47]. Food is consumed without taking into consideration its nutrient content. This fact is known and exploited by businesses and the food industry, which offer increasingly practical, palatable, durable, and more attractive food to the general population. Processed foods, which are poor in antioxidant nutrients ( $\mathrm{Zn}, \mathrm{Cu}$, and vitamins $\mathrm{A}, \mathrm{C}$, and $\mathrm{E})$, are more accessible to all age groups, and the increased consumption of these products is considered one of the factors contributing to the increased prevalence of obesity and chronic diseases [48].

This study has some limitations. This is a cross-sectional study, which limits the findings to the level of association. Certain problems have been identified from the diet diaries of the adolescents (records). This may have been a problem in the two $\mathrm{R} 24 \mathrm{H}$ that were utilized to estimate alimentary consumption. The variance ratio for the intake of nutrients in this population was twice as great as that in adults, partly due to over or or low reporting of ingestion [49]. Therefore, to reduce these errors, the nutrients were corrected in accordance with interpersonal variability.

Considering the importance of these antioxidant nutrients on lipid metabolism and cardiometabolic risk, food and nutritional 
education activities should be initiated, which are in accordance with the food guidelines that emphasize the adoption of food standards based on in natura or minimally processed foods to reduce and prevent non-communicable diseases. The increased consumption of foods rich in substances that fight against oxidative stress is important, not merely the intake of antioxidants in isolation or in supplemental form because the dose and duration of supplementation of each individual micronutrient remains controversial.

\section{CONCLUSION}

Associations between the intake of antioxidant nutrients ( $\mathrm{Zn}, \mathrm{Cu}$, and vitamins $A, C$, and E) as well as lipid alterations and cardiometabolic risk were observed in the present study. The presence of these associations indicates the need for interventions in the younger population, with emphasis on consuming nutrient-rich foods that improve the health profile of adolescents.

\section{CONTRIBUTORS}

LM NASCIMENTO participated in the design of research and data collection, performed biochemical and statistical analyzes, interpreted the results and wrote the article; KRO GOMES participated in the conception of the study, of the sample design and revised the article; MDM MASCARENHAS, CES MIRANDA, and TME ARAÚJO participated in the study design and reviewed the article; KMG FROTA participated in the design of the research, conducted the biochemical and statistical analyzes and reviewed the article. All authors approved the final version of the manuscript.

\section{REFERENCES}

1. Ding $W$, Cheng $H$, Yan $Y$, Zhao $X$, Chen $F$, Huang $\mathrm{G}$, et al. 10-Year trends in serum lipid levels and dyslipidemia among children and adolescents from several schools in Beijing, China. J Epidemiol. 2016;26(12):637-45. http://dx.doi.org/10.2188/jea. JE20140252
2. Faludi AA, Izar MCO, Saraiva JFK, Chacra APM, Bianco HT, Afiune Neto A, et al. Atualização da Diretriz Brasileira de Dislipidemias e Prevenção da Aterosclerose: 2017. Arq Bras Cardiol. 2017;109(2 Supl 1):1-76.

3. Ye Y, Li J, Yuan Z. Effect of antioxidant vitamin supplementation on cardiovascular outcomes: A meta-analysis of randomized controlled trials. PLoS One. 2013;8(2):e56803. http://dx.doi.org/10.1371/ journal.pone.0056803

4. Vasilev V, Matrozova J, Elenkova A, Vandeva S, Kirilov G, Zacharieva S. Asymmetric Dimethylarginine (ADMA) and soluble vascular cell adhesion molecule 1 (sVCAM-1) as circulating markers for endothelial dysfunction in patients with pheochromocytoma. Exp Clin Endocrinol Diabetes. 2013;21(9):551-5. http://dx.doi.org/10.10 55/s-0033-1353183

5. Weiss TW, Arnesen H, Seljeflot I. Components of the interlukin- 6 transsignalling system are associated with the metabolic syndrome, endothelial dysfunction and arterial stiffness. Metabolism. 2013;62(7):1008-13. http://dx.doi. org/10.1016/j.metabol.2013.01.019

6. SitiHawa N, Yusof K, Kamsiah J. The role of oxidative stress, antioxidants and vascular inflammaton in cardiovascular disease: A review. Vasc Pharmacol. 2015;71:40-56. http://dx.doi.org/10.1016/J.vph.2015. 03.005

7. Suarez-Ortegón MF, Ordoñez-Betancourth JE, Aguilar-de-Plata C. Dietary zinc intake is inversely associated to metabolic syndrome in male but not in female urban adolescents. Am J Hum Biol. 2013;25(4):550-4. http://dx.doi.org/10.1002/ajhb. 22408

8. García OP, Ronquillo D, Caamaño MC, Martínez G, Camacho M, López V. Zinc, iron and vitamins A, $\mathrm{C}$ and $\mathrm{E}$ are associated with obesity, inflammation, lipid profile and insulin resistance in Mexican school-aged children. Nutrients. 2013;5(12):5012-30. http://dx.doi.org/10.3390/nu5125012

9. Benstoem C, Goetzenich A, Kraemer S, Borosch S, Manzanares W, Hardy G. Selenium and its supplementation in cardiovascular disease: What do we know? Nutrients. 2015;7(5):3094-118. http:// dx. doi.org/10.3390/nu7053094

10. Gaur GS, Dixit AK. Effect of vitamin C on serum lipid profile in normal human subjects: A study. Inter J Cur Res. 2011;3(11):286-8.

11. Wang $X$, Ouyang $Y$, Liu J, Zhu M, Zhao G, Bao $W$, et al. Fruit and vegetable consumption and mortality from all causes, cardiovascular disease, and cancer: Systematic review and dose-response meta-analysis of prospective cohort studies. BMJ. 
2014;349:g4490. http://dx.doi.org/10.1136/bmj. g4490

12. Pinho LD, Silveira MF, Botelho AC, Caldeira AP. Identification of dietary patterns of adolescents attending public schools. J Pediatr. 2014;90(3):267-72. http://dx.doi.org/10.1016/j.jped.2013.04.006

13. Souza AM, Barufaldi LA, Abreu GA, Giannini DT, Oliveira $\mathrm{CL}$, Santos MM, et al. ERICA: ingestão de macro e micronutrientes em adolescentes brasileiros. Rev Saúde Pública. 2016;50(Supl 1):5s. http://dx.doi.org/10.1590/S01518-8787.201605 0006698

14. Luiz ES, Torres TG, Hagnanini MMF. Planejamento amostral. In: Luiz RR, Costa AJL, Nadanovsky P. Epidemiologia e bioestatística na pesquisa odontológica. São Paulo: Atheneu; 2005.

15. Instituto Nacional de Estudos e Pesquisas Educacionais Anísio Teixeira (Brasil). Educação básica: Censo escolar. Brasília: Inep; 2014 [acesso 14 jun 2015]. Disponível em: http://www.dataescola brasil.inep.gov.br/dataEscolaBrasil/home.seam

16. Bloch KV, Klein CH, Szklo M, Kuschnir MCC, Abreu GA, Barufaldi LA, et al. Prevalências de hipertensão arterial e obesidade em adolescentes brasileiros. Rev Saúde Pública. 2016;50(Supl 1):9s. http://dx.doi.org/10.1590/S01518-8787.201605 0006685

17. Armitage P. Statistical method in medical research. New York: John Wiley and Sons; 1981.

18. Ministério da Saúde (Brasil). Conselho Nacional de Pesquisa com Seres Humanos. Resolução ${ }^{\circ}$ 466/12. Diário Oficial da União. 2012 [acesso 2016 mar 17];(12):59; Seção 1. Disponível em: http://bvsms.saude.gov.br/bvs/saudelegis/cns/ 2013/res046 6_12_12_2012.html

19. Cameron N. Anthropometric measurements. In: Cameron N, editor. The measurement of human growt. London: Croom Helm; 1984.

20. Jelliffe DB, Jelliffe EFP. Anthropometry: Major measurements. In: Jelliffe DB, Jelliffe EFP. Community nutritional assessment with special reference to less technically developed countries. 2nd ed. London: Oxford University Press; 1989.

21. World Health Organization. Multicentre Growth Reference Study Group. WHO child growth standards: Length/height-forage, weight-for-age, weight-for-length, weight-for height and body mass index-for-age: Methods and development. Geneva: World Health Organization; 2007.

22. Callaway CW, Chumlea WC, Bouchard C, Himes $J H$, Lohman TG, Martin AD, et al. Circunferences. In: Lohman TG, Roche AF, Martorell R, editors. Anthropometric standardization reference manual. Champaign: Human Kinetics; 1988. p.39-54.
23. Fredriks AM, van Buuren S, Verloove-Vanhorick MFSP, Wit JM. Are age references for waist circumference, hip circumference and waist-hip ratio in Dutch children useful in clinical practice? Eur J Pediatr. 2005;164(4):216-22. http://dx.doi. org/0.1007/s00431-004-1586-7

24. Ashwell M, Hsieh SD. Six reasons why the waist-toheight ratio is a rapid and effective global indicator for health risks of obesity and how its use could simplify the international public health message on obesity. Int J Food Sci Nutr. 2005; 56:303-7. http://dx.doi.org/10.1080/09637480500195066

25. Moshfegh AJ, Rhodes DG, Baer DJ, Murayi T, Clemens JC, Rumpler WV. The US Department of Agriculture Automated Multiple-Pass Method reduces bias in the collection of energy intakes. Am J Clin Nutr. 2008;88(2):324-32.

26. Verly-Júnior E, Castro MA, Fisberg RM, Marchioni DML. Precision of usual food intake estimates according to the percentage of individuals with a second dietary measurement. J Acad Nutr Diet. 2012;122(7):1015-20. http://dx.doi.org/10. 1016/j.jand.2012.03.028

27. German Institute of Human Nutrition PotsdamRehbrücke [site].The Multiple Source Method (MSM). Nuthetal: Dife; 2017 [cited 20 Jan 2017]. Available from: https://msm. dife.de

28. Malachias MVB, Souza WKSB, Plavnik FL, Rodrigues CIS, Brandão AA, Neves MFT, et al. 7 nuthetal: Dife; 2017. Diretriz Brasileira de Hipertensão Arterial. Arq Bras Cardiol. 2016;107(3 Supl 3):1-83.

29. Molina MCB, Faria CP, Montero MP, Cade NV, Mill JG. Fatores de risco cardiovascular em crianças de 7 a 10 anos de área urbana, Vitória, Espírito Santo, Brasil. Cad Saúde Pública. 2010;26(5):909-17. http://dx.doi.org/10.1590/S0102-311X2010000 500013

30. Christofaro DGD, Ritti-Dias RM, Fernades RA, Polito $\mathrm{MD}$, Andrade SM, Cardoso JR, et al. Detecção de hipertensão arterial em adolescentes através de marcadores gerais e adiposidade abdominal. Arq Bras Cardiol. 2011;96(6):465-70. http://dx.doi. org/10.1590/S0066-782X2011005000050

31. Friedewald WT, LevyRI, Fredrickson DS. Estimation of the concentration of low-density lipoprotein cholesterol in plasma, without use of the preparative ultracentrifuge. Clin Chem. 1972;18(6):499-502.

32. American Diabetes Association Position Statement. Diagnosis and classification of diabetes mellitus. Diab Care. 2010;33(Suppl 1):S62-9. http://dx.doi. org/10.2337/dc10-S062

33. Eisenmann JC. On the use of a continuous metabolic syndrome score in pediatric research. Cardiovasc Diabetol. 2008;7:17. http://dx. doi.org/10. 1186/1475-2840-7-17 
34. Moreira C, Moreira P, Abreu S, Santos PC, Moreira-Silva I, Póvoas $S$, et al. Vitamin D Intake and cardiometabolic risk factors in adolescents. Metab Syndr Relat Disord. 2014;12(3):171-7. http://dx.doi.org/10.1089/met.2013.0065

35. Faria-Neto JR, Bento VFR, Baena CP, Olandoski M, Gonçalves LGO, Abreu GA, et al. ERICA: prevalência de dislipidemia em adolescentes brasileiros. Rev Saúde Pública. 2016;50(Supl 1):10s. http://dx.doi.org/10.1590/S01518-8787.2016 050006723

36. Kuschnir MCC, Bloch KV, Szklo $M$, Klein $C H$, Barufaldi LA, Abreu GA, et al. ERICA: prevalência de síndrome metabólica em adolescentes brasileiros. Rev Saúde Pública. 2016;50(supl 1):11s. http://dx.doi.org/10.1590/s01518-8787.2016 050006701

37. Shen $H$, MacDonald R, Bruemmer D, Stromberg A, Daugherty A, Li X. Zinc deficiency alters lipid metabolism in LDL receptor-deficient mice treated with rosiglitazone. J Nutr. 2007;137(11): 2239-45.

38. Partida-Hernandez G, Arreola F, Fenton B, Cabeza M, Roman-Ramos R, Revilla-Monsalve MC. Effect of zinc replacement on lipids and lipoproteins in type 2-diabetic patients. Biomed Pharmacother. 2006;60(4):161-8. http://dx.doi.org/10.1016/j. biopha. 2006.02.004

39. Kadhim HM, Ismail SH, Hussein KI, Bakir IH, Sahib AS, Khalaf BH. Effects of melatonin and zinc on lipid profile and renal function in type 2 diabetic patients poorly controlled with metformin. J Pineal Res. 2006;41(2):189-93. http://dx.doi.org/10.11 11/j.1600-079X.2006.00353.x

40. Galhardi CM, Diniz YS, Rodrigues HG, Faine LA, Burneiko RC, Ribas BO. Beneficial effects of dietary copper supplementation on serum lipids and antioxidant defenses in rats. Ann Nutr Metab. 2005;49(5):283-8. http://dx.doi.org/10.1159/000 087294

41. Aeberli I, Hurrell RF, Zimmermann MB. Overweight children have higher circulating hepcidin concentrations and lower iron status but have dietary iron intakes and bioavailability comparable with normal weight children. Int J Obes.
2009;33(10):1111-7. http://dx.doi.org/10.1038/ijo. 2009

42. Kiefer FW, Orasanu G, Nallamshetty S, Brown JD, Wang $\mathrm{H}$, Luger $\mathrm{P}$, etal. Retinaldehyde dehydrogenase 1 coordinates hepatic gluconeogenesis and lipid metabolism. Endocrinology. 2012;153(7):308999. http://dx.doi.org/10.1210/en.2011-210

43. Ashor AW, Siervo M, Velde F, Willis ND, Mathers JC. Systematic review and meta-analysis of randomised controlled trials testing the effects of vitamin $C$ supplementation on blood lipids. Clin Nutr. 2015;35(3):626-37. http://dx.doi.org/10.10 16/j.clnu.2015.05.021

44. McRae MP. Vitamin C supplementation lowers serum low-density lipoprotein cholesterol and triglycerides: a meta-analysis of 13 randomized controlled trials. J Chiropr Med. 2008;7(2):48-58. http://dx.doi.org/10.1016/j.jcme.2008.01.002

45. Charlton-Menys V, Durrington PN. Human cholesterol metabolism and therapeutic molecules. Exp Physiol. 2008;93(1):27-42. http://dx.doi.org/10.1 113/expphysiol.2007.035147

46. Chambial S, Dwivedi S, Shukla KK, John PJ, Sharma P. Vitamin $C$ in disease prevention and cure: An overview. Indian J Clin Biochem. 2013;28(4):31428. http://dx.doi.org/10.1007/s12291-013-0375-3

47. Louzada MLC, Martins APB, Canella DS, Baraldi LG, Levy RB, Claro RM, et al. Impact of ultra-processed foods on micronutrient content in the Brazilian diet. Rev Saúde Pública. 2015;49:45. http://dx.doi. org/10.1590/S0034-8910.2015049006211

48. Bielemann RM, Motta JVS, Minten GC, Horta BL, Gigante DP. Consumo de alimentos ultraprocessados e impacto na dieta de adultos jovens. Rev Saúde Pública. 2015;49-28. http://dx.doi.org/10. 1590/S0034-8910.2015049005572

49. Livingstone MB, Robson PJ, Wallace JM. Issues in dietary intake assessment of children and adolescents. Br J Nutr. 2004. 92(Suppl 2):S213-22. http://dx.doi.org/10.1079/BJN20041169

Received: September 22, 2017 Final version: December 11, 2017 Approved: March 6, 2018 